\title{
Use of Health Services and Family Health Strategy Households Population Coverage in Brazil
}

\author{
Utilização dos Serviços de Saúde e Estratégia Saúde da Família \\ Cobertura da População Domiciliar no Brasil
}

Otávio Pereira D’Avila (https://orcid.org/0000-0003-1852-7858) ${ }^{1}$

Luiz Alexandre Chisini https://orcid.org/0000-0002-3695-0361) ${ }^{2}$

Francine dos Santos Costa (https://orcid.org/0000-0001-9558-937X) ${ }^{2}$

Mariana Gonzales Cademartori (https://orcid.org/0000-0002-2433-8298) ${ }^{1}$

Lucas Brum Cleff (https://orcid.org/0000-0002-9333-8128) 1

Eduardo Dickie de Castilhos (https://orcid.org/0000-0002-7072-6558) ${ }^{1}$
${ }^{1}$ Faculdade de Odontologia, Universidade Federal de Pelotas. Rua Gonçalves Chaves, Centro. 96015560 Pelotas RS Brasil. otaviopereiradavila@ gmail.com

${ }^{2}$ Faculdade de Odontologia, Universidade do Vale do Taquari. Lajeado RS Brasil.
Abstract The objective of this study is to describe the profile of use of primary health care services, estimated by the PNS, of the population living in households registered and not registered with the Famly Health Strategy - FHS, in the years 2013 and 2019. Cross-sectional study carried out using microdata from national health surveys 2013 and 2019. The sample originated from a master sample, consisting of a set of units from selected areas in a register..The variables sex, age, skin color, income, education, self-perceived health, home registered with the FHS, medical care in the last year, type of service you seek when you are ill were selected. The dependent variables were use of health services and use of public health services. The dependent and independent variables were described with the respective confidence interval and adjusted logistic regression was performed for each outcome analyzed. In public health services, lower income, have chronic diseases (arterial hypertension or high cholesterol), be pregnant, and having a bad self-perception of health were associated with used more health services in both periods. Living in registered households was associated with more used health services (public or private). The family health strategy is an important strategy for expanding access equally.

Key words Primary Health Care, Family Health Strategy, Health services, Acess
Resumo O objetivo deste estudo é descrever o perfil de utilização dos serviços de atenção primária à saúde, estimado pela Pesquisa Nacional de Saúde (PNS), da população residente em domicílios cadastrados e não cadastrados na Estratégia de Saúde da Família (ESF), nos anos de 2013 e 2019. Estudo transversal realizado com microdados dos inquéritos nacionais de saúde entre 2013 e 2019. A amostra originou-se de uma amostra mestra, composta por um conjunto de unidades de áreas selecionadas em um cadastro. Variáveis sexo, idade, cor da pele, renda, escolaridade, autopercepção de saúde, domicílio cadastrado na ESF, atendimento médico no último ano, tipo de serviço que você procura quando está doente foram selecionados. As variáveis dependentes foram uso de serviços de saúde e uso de serviços públicos de saúde. As variáveis dependentes e independentes foram descritas com os respectivos intervalos de confiança e foi realizada regressão logística ajustada para cada desfecho analisado. Nos serviços públicos de saúde, menor renda, ter doenças crônicas (hipertensão arterial ou colesterol alto), estar grávida e ter uma autopercepção de saúde ruim estiveram associados à maior utilização de serviços de saúde nos dois períodos. Morar em domicílios cadastrados na ESF foi associado aos serviços de saúde mais utilizados (públicos ou privados). A estratégia de saúde da família é uma estratégia importante para expandir o acesso de forma igualitária.

Palavras-chave Atenção Primária à Saúde, Estratégia Saúde da Família, Serviços de saúde 


\section{Introduction}

Primary Health Care (PHC) is the structural axis of a health system. This is the first level of access, organized to offer a longitudinal and comprehensive service, coordinating care within the health system itself (essential attributes). PHC also has guidelines for organizing care geared to the needs of families, communities, observing the cultural characteristics of each population. These are considered attributes derived from $\mathrm{PHC}^{1}$.

PHC aims to balance two goals of a health system: to optimize the health of individuals and the population; provide equity in the distribution of resources, both proper to care and financial ${ }^{2}$.

The Family Health Strategy (FHS) is the great Brazilian bet to structure PHC services in the country. In the last 20 years, there has been a strong expansion of the FHS in all regions of the country $^{3}$. At the end of 2019, there were almost 45 thousand Basic Health Units, with 43,458 FHS teams with potential coverage of about 150 million people 4 . advances in FHS coverage have enabled a reduction in infant mortality and preventable mortality, a reduction in hospitalizations for sensitive conditions, among other advances $^{5,6}$. On the other hand, there is a significant decrease in the speed of health gains in the face of public investment: decreased vaccination coverage, loss of speed in reducing child mortality, a large proportion of preventable hospital admissions, in addition to enormous difficulty in managing diseases chronic diseases, aging, and also coping with syphilis and HIV .

National home-based surveys are important tools to study and understand the health needs of the population, coverage of health services, profile of access and use, among others. The National Health Survey (PNS), conducted in 2019, with a sample of 86,820 households, collected information on the performance of the single health system.

The objective of this study is to describe the profile of use of primary health care services, estimated by the PNS, of the population living in households registered and not registered with the FHS, in the years 2013 and 2019.

\section{Methodology}

The PNS sample originated from a master sample, consisting of a set of units from selected areas in a register, in order to meet the subsample selections for several different surveys provided for in the Integrated Home Survey System (IHS
/ IBGE), such as the National Household Sample Survey and the Household Budget Survey. Such units are conceptualized as primary sampling units (PSU), within the sample planning of the researches that use the master sample, as in the case of the PNS ${ }^{8}$.

The sampling strategy consisted of (i) a three-stage conglomerate plan, with stratification of the UPA (in this case, census sectors or set of sectors) and selection of these for the master sample, with probability proportional to the size, defined by the number of households permanent private individuals, and (ii) the selection for the PNS sample, with an equally proportional probability.

The second stage consisted of the selection of households from the National Register of Addresses for Statistical Purposes, in its most recent update (carried out for the execution of the Continuous National Household Sample Survey 2019) before the completion of this stage of the sampling plan, by simple random sampling. Then, within each household, a resident aged 15 or over was randomly selected, based on the list of residents obtained at the time of the interview. To scale the sample size with the level of precision desired for the estimates, some indicators from the 2013 edition of the PNS were considered, such as data from chronic non-communicable diseases (diabetes, hypertension, depression), violence, use of health services, possession of a plan health, smoking, physical activity and alcohol consumption, among others?

\section{Data collection National Health Survey}

The organization of collections and the coordination of fieldwork, carried out by Brazilian Institute of Geography and Statistics (IBGE), involved collection agents (interviewers), supervisors (supervision of data collection and management of collection agents) and coordinators (responsible for research in a given state or central unit) ) of IBGE's own staff'.

The training of coordinators and others involved consisted of stages: at first, the coordinators of IBGE state units were trained through a face-to-face workshop held in the city of Bento Gonçalves, Rio Grande do Sul State. Participants became multiplier agents and, upon returning to their units, passed on the training content to supervisors and collection agents. The field team (coordinators, supervisors and collection agents) participated, throughout the process data collection, simultaneous training, with the possibility of online questioning8. 
The interviews were conducted with the use of mobile collection devices (MCD), programmed to "jump" over items in the questionnaire and for critical analysis of the variables. Upon arriving at the selected household, first the interviewers made contact with the responsible person or another resident. The agent explained to the residents the objectives, the data collection procedure and the importance of their participation in the research. At that time, a list of all individuals residing in the household was filled out, regardless of whether or not they agreed to participate in the research ${ }^{8}$.

Then, the resident was identified who would provide information about the questionnaires at home and of all the residents of the household, in addition to the draw of the resident of 15 years and more to answer the interview. individual. The interviews were scheduled at the most convenient time for the residents. Two or more visits were planned in each household 8 .

In 2013, records of interviews were obtained in 64,348 households and the informant of each responded to the others about the FHS coverage. Thus, valid information was collected for about 205,000 residents. For data analysis, expansion factors or sample weights were used for PSUs, for households and all residents and for the selected resident.

In 2019, records of interviews were obtained in 86,820 households and the informant of each responded to the others about the FHS coverage. Thus, valid information was collected for about 134,221 residents. For data analysis, expansion factors or sample weights were used for PSUs, for households and all residents and for the selected resident.

\section{Variables}

The households registered in the FHS were presented in proportions, and to estimate the number of people per household, the division was made: number of households registered in the family health unit / number of households interviewed in the PNS.

Brazilian major regions, census situation, Sexsex, age, skin color, income, education, self-perceived health, home registered in the FHS , use of medical care in the last year (public and private), type of service you seek when you are ill, chronic diseases and pregnancy, were independent variables selected for the year 2013 and 2019.

The independent variables were categorized: Sex (Male, Female); Age (18-29 years-old, 30-39 years-old, 40-49 years-old, 50-59 years-old, 60 years-old or more); Skin color (White, Brown, Black, Yellow, Indigenous); Family and household income in quintiles, Head of household education (none, Incomplete Elementary / Middle school, Elementary / Middle school, High school, Undergraduation or more); search for health service in case of illness (private, public, pharmacy / others). Self-reported health condition - arterial hypertension, diabetes, high cholesterol, and (yes / no); pregnancy - (yes / no); the self-perceived health variable is the categorization (very good, good, regular, bad, very bad). Brazilian major regions (North, Northeast, Southeast, South, and Midwest); census situation (urban/rural); register in a family health unit (yes/no).

The variable of use to public health services was the outcome of association analysis and was built through Tthe question was built: "In the last two weeks, looked for a place, service or health professional for care related to one's own health", where only individuals who accessed public services were considered.

\section{Data Analysis}

The proportions of households registered in the FSH were stratified according to Major Regions, Federation Units (UF). The proportion and their 95\% confidence intervals $(95 \% \mathrm{CI})$ were described; and the absolute numbers have been estimated. Descriptive analysis of the use of medical care (public and private) in the last year was also carried out, considering living in households registered in the FHS . In addition, the co-variables were used for, region, sex, age, income, education, skin color, search for health care in case of illness, self-reported health condition (diabetes, hypertension, high cholesterol, pregnant woman) and self-perceived health. Then, adjusted logistic regression was performed to establish the association between the independent variables and the outcome "use to public health services". To the co-variables investigated in this analysis were: Register in a Family Health unit, census situation, Brazil region, sex, age, skin color, family income, household wealth, schooling of the head of household, self-reported health condition (diabetes, hypertension, high cholesterol, pregnant woman) and self-perceived health.

The inclusion of independent variables in the model was performed using backward stepwise considering a p-value $<0.2$ for the adjusted one. The crude and adjusted odds ratio and their $95 \%$ confidence intervals $(95 \% \mathrm{CI})$ were described. 
The data were analyzed by the software Stata 16 , through the survey module, which considers the effects of complex sampling.

\section{Results}

The descriptive analysis of the households registered with the FHS showed that between the years 2013 and 2019 there was an expansion of coverage. In 2013, 54.7\% of households were registered with the FHS, in PNS 2019 this proportion jumped to $61.5 \%$ of the sampled households. Considering the number of people per household, the potential coverage doubled (79.610.000 to 134.121.000). Rural households had a higher proportion of registered households than urban households. The northeast region had the highest coverage of registered households in both periods analyzed, at the other extreme, the southeast region had the lowest proportion of registered households (Table 1).

It is possible to observe people who live in households registered in FSH use health services more. This is observed both in 2013 and in 2019, and for this last period the differences deepen (Table 2). Only $23.8 \%$ of people living in households not registered in FHS in the southeast of the country did not use health services in 2019, while $79.6 \%$ of people living in registered households in the northeast used health services in the last 12 months. The results also point out that people with lower income and education have used more health services than the others, as well as people who have some chronic health condition (Table 2).

The Table 3 explore the associated factor to used public health services (SUS). The results showed that not belonging to a registered household with the FHS decreases the chance of using public health services (SUS) OR 0.65 (0.55 $0.78)$ in 2013 and OR $0.86(0.77-0.96)$ in 2019. Living in the countryside, which was not associated in adjusted analysis in 2013, was associated with a decrease of use SUS services in 2019 (OR 0.87 , CI95\% $0.78-0.97)$. In both periods, living in the northern region of the country was a factor of difficulty (risk) in using public health services.

Regarding age, despite older individuals were only associated with increase of service use in crude analyze in 2013, individuals of 40-49 years (OR 1.21, CI95\% $1.01-1.44$ ) and 50-59 years (OR 1.27, CI95\% 1.07 - 1.51) were associated in adjusted model in 2019.Both in 2013 as in 2019 individuals with black, indigenous or brown skin color were associated with increase of public health service use in crude analyses $(\mathrm{p}<0.001)$. After the adjustments, the associations were lost. While education level was not associated in adjusted analysis, high levels of income - in both periods - were associated with decrease in public health service use $(\mathrm{p}<0.001)$, establishing an equity performance. The health conditions evaluated showed a higher use of public health services than those that did not present this condition ( $\mathrm{p}$ $<0.001$ ), it should be noted that the differences reduced in 2019. Regarding self-perceived health, the high use by those who stand out that are perceived in the worst health conditions both in 2013 (OR 12.07, CI95\% 6.24 - 23.4) and in 2019 (OR 4.65, CI95\% 3.45 - 6.26).

\section{Discussion}

The results of the present article demonstrated that there was an increase $(54.7 \%$ to $61.3 \%)$, during the evaluated period, of the studied population that refers to be registered in the family health units, being greater in the rural compared to the urban area. The Northeast region had the highest percentage, followed by the South, the Southeast had the lowest proportion. As for the units of the federation, there was an increase in registered households in almost all locations, except in the state of Tocantins. Living in a home registered with the FHS was an important factor for the use of public or private health services.

Adjusted analyzes showed that having health conditions that require continuous care (high blood pressure, high cholesterol, pregnancy) was a factor associated with greater use of public health services. Moreover, it was also observed that living in the rural area (in 2019), have no register in a Family Health Unit, lower income, and bad self-perception of health were associated with the outcome. The FHS is the Brazilian option for organizing Primary Health Care (PHC) services ${ }^{910}$.

In the last few years, it underwent a strong expansion of these services reaching, in 2019, 43,755 teams with a potential coverage of $64.47 \%{ }^{11}$. PHC is an organized service to answer the most frequent health needs of the population, being the main gateway to a health system, responsible for the health of a defined population, based on longitudinal and equitable care. The PNS 2013/2019 data demonstrate that the FHS achieves this objective to the extent that it is present in all entities of the federation and facilitates the use of public health services, especially for those individuals who are historically excluded from access to health services. health 
Table 1. Proportion and total number of registered households and people living in these places in a health unit of the family, 2013 and 2019.

\begin{tabular}{|c|c|c|c|c|c|c|}
\hline \multirow{3}{*}{$\begin{array}{l}\text { Brazil, Major Regions } \\
\text { and Federation Units }\end{array}$} & \multicolumn{3}{|c|}{$\begin{array}{l}\text { Households registered in a family health } \\
\text { unit } 2013\end{array}$} & \multicolumn{3}{|c|}{$\begin{array}{c}\text { Households registered in a family health } \\
\text { unit } 2019\end{array}$} \\
\hline & \multicolumn{2}{|c|}{ Total (\%) } & \multirow{2}{*}{$\begin{array}{c}\text { Total People } \\
\text { (absolute } \\
\text { number } x \text { 1000) }\end{array}$} & \multicolumn{2}{|c|}{ Total (\%) } & \multirow{2}{*}{$\begin{array}{c}\text { Total People } \\
\text { (absolute } \\
\text { number x 1000) }\end{array}$} \\
\hline & Proportion & $\begin{array}{c}\text { Confidence } \\
\text { interval 95\% }\end{array}$ & & Proportion & $\begin{array}{l}\text { Confidence } \\
\text { interval 95\% }\end{array}$ & \\
\hline Brazil & 54.7 & $53.1-56.1$ & 79.610 .000 & 61.5 & $60.2-62.7$ & 134.121 .000 \\
\hline Urban & 51.9 & $50.2-53.5$ & 62.230 .000 & 58.8 & $57.4-60.2$ & 97.306 .000 \\
\hline Rural & 72.1 & $69.1-74.9$ & 17.380 .000 & 68.5 & $76.7-80.3$ & 36.815 .000 \\
\hline North & 52.4 & $49.6-55.3$ & 16.874 .000 & 61.2 & $58.9-63.4$ & 24.882 .000 \\
\hline Rondônia & 56.9 & $51.6-62.1$ & 2.118 .000 & 52.1 & $47.7-56.4$ & 2.452 .000 \\
\hline Acre & 48.1 & $42.6-53.6$ & 1.978 .000 & 54.0 & $49.4-58.4$ & 2.733 .000 \\
\hline Amazonas & 51.3 & $46.3-56.2$ & 3.593 .000 & 56.7 & $51.8-61.4$ & 5.050 .000 \\
\hline Roraima & 54.3 & $48.9-59.5$ & 2.207 .000 & 53.3 & $48.0-58.6$ & 3.107 .000 \\
\hline Pará & 46.2 & $41.0-51.4$ & 2.467 .000 & 62.3 & $58.4-66.1$ & 5.400 .000 \\
\hline Amapá & 33.7 & $28.4-39.4$ & $1,332.000$ & 46.4 & $39.9-53.0$ & 2.156 .000 \\
\hline Tocantins & 93.2 & $91.1-94.8$ & 3.179 .000 & 89.7 & $87.9-91.6$ & 3.934 .000 \\
\hline Northeast & 66.3 & $64.4-68.2$ & 2.701 .000 & 72.2 & $70.7-73.7$ & 53.185 .000 \\
\hline Maranhão & 65.1 & $59.2-70.5$ & 2.406 .000 & 67.2 & $64.1-70.2$ & 8.158 .000 \\
\hline Piauí & 79.8 & $74.8-84.1$ & 3.482 .000 & 90.3 & $88.3-92.1$ & 5.958 .000 \\
\hline Ceará & 66.5 & $62.1-70.6$ & 4.090 .000 & 72.6 & $69.5-75.4$ & 7.929 .000 \\
\hline Rio Grande do Norte & 64.7 & $59.5-69.6$ & 2.403 .000 & 70.3 & $65.7-74.5$ & 5.057 .000 \\
\hline Paraíba & 80.2 & $75.7-84.0$ & 3.406 .000 & 86.3 & $83.0-89.1$ & 6.104 .000 \\
\hline Pernambuco & 64.6 & $60.2-68.6$ & 4.015 .000 & 72.1 & $68.4-75.4$ & 6.536 .000 \\
\hline Alagoas & 67.1 & $61.5-72.3$ & 2.420 .000 & 66.1 & $60.9-71.0$ & 4.127 .000 \\
\hline Sergipe & 71.9 & $67.9-75.5$ & 2.858 .000 & 82.0 & $78.9-84.7$ & 4.716 .000 \\
\hline Bahia & 60.7 & $55.2-66.0$ & 2.621 .000 & 66.9 & $64.5-71.1$ & 4.600 .000 \\
\hline Southeast & 47.2 & $44.4-50.0$ & 16.711 .000 & 53.6 & $51.2-56.0$ & 25.520 .000 \\
\hline Minas Gerais & 71.5 & $66.3-71.1$ & 6.078 .000 & 72.3 & $68.1-76.2$ & 8.657 .000 \\
\hline Espírito Santo & 56.3 & $49.7-62.8$ & 2.507 .000 & 62.0 & $57.4-66.5$ & 4.974 .000 \\
\hline Rio de Janeiro & 34.0 & $30.4-37.8$ & 3.896 .000 & 47.4 & $44.1-50.7$ & 5.319 .000 \\
\hline São Paulo & 40.2 & $36.3-44.3$ & 5.230 .000 & 46.6 & $42.9-50.4$ & 6.570 .000 \\
\hline South & 57.5 & $53.7-61.2$ & 9.863 .000 & 66.7 & $64.3-69.1$ & 17.223 .000 \\
\hline Paraná & 55.2 & $48.8-61.5$ & 4.028 .000 & 67.8 & $63.7-71.6$ & 6.117 .000 \\
\hline Santa Catarina & 75.9 & $69.1-81.6$ & 2.850 .000 & 86.6 & $83.9-88.9$ & 6.960 .000 \\
\hline Rio Grande do Sul & 48.7 & $42.7-54.7$ & 2.985 .000 & 53.1 & $48.9-57.2$ & 4.146 .000 \\
\hline Midwest & 53.7 & $50.6-56.8$ & 8.461 .000 & 59.3 & $56.3-62.3$ & 13.311 .000 \\
\hline Mato Grosso do Sul & 75.3 & $71.2-79.0$ & 2.939 .000 & 76.5 & $73.1-79.6$ & 4.556 .000 \\
\hline Mato Grosso & 64.9 & $58.8-70.6$ & 1.959 .000 & 74.4 & $70.1-78.2$ & 3.663 .000 \\
\hline Goiás & 57.8 & $52.7-62.8$ & 2.942 .000 & 59.2 & $53.5-64.6$ & 3.403 .000 \\
\hline Distrito Federal & 13.4 & $10.6-16.9$ & 621.000 & 28.5 & $24.7-32.6$ & 1.689 .000 \\
\hline
\end{tabular}

Source: Author's elaboration.

as non-whites, lower income, less education and for those who live in rural areas. Previous studies have shown that women, lower income, less education, poorer self-perception of health, having a chronic health condition and advancing age are related to greater use of health services in the FHS $^{12-14}$. An unusual finding for the use of health services was the protective factor found for nonwhites. It is possible to speculate that the Bra- zilian FHS has built bonding relationships and work organization capable of overcoming some discriminatory barriers that may be associated with the use of services and skin color ${ }^{15}$.

In addition, the increased use of health services for people with health conditions that require continuous care shows that the FHS traces a correct path for expanding access in an equitable way. However, the effectiveness of care cannot 
Table 2. Description of use of medical health services (public or private) according to registered in a family health unit $^{*}$ in 2013 and 2019.

\begin{tabular}{|c|c|c|c|c|}
\hline & \multicolumn{2}{|c|}{ Use of health services } & \multicolumn{2}{|c|}{ Use of health services } \\
\hline & $\begin{array}{l}\text { Registered in a } \\
\text { family health } \\
\text { unit } 2013 \\
\end{array}$ & $\begin{array}{l}\text { Not registered in } \\
\text { a family health } \\
\text { unit } 2013\end{array}$ & $\begin{array}{c}\text { Registered in a } \\
\text { family health unit } \\
2019\end{array}$ & $\begin{array}{c}\text { Not registered in } \\
\text { a family health } \\
\text { unit } 2013\end{array}$ \\
\hline & $\%(\mathrm{CI} 95 \%)$ & $\%(\mathrm{CI} 95 \%)$ & $\%(\mathrm{CI} 95 \%)$ & $\%(\mathrm{CI} 95 \%)$ \\
\hline \multicolumn{5}{|l|}{ Region } \\
\hline North & $60.7(57.6-63.6)$ & $39.3(36.4-42.4)$ & $68.9(66.5-71.2)$ & $31.1(28.8-33.5)$ \\
\hline Northeast & $74.0(72.0-75.9)$ & $26.0(24.1-28.0)$ & $79.6(78.1-81.0)$ & $20.4(18.9-21.9)$ \\
\hline Southeast & $53.0(50.0-56.0)$ & $47.0(43.9-50.0)$ & $59.9(57.4-62.5)$ & $40.1(37.5-42.5)$ \\
\hline South & $62.8(58.9-66.5)$ & $37.2(33.5-41.1)$ & $76.2(73.9-78.4)$ & $23.8(21.6-26.1)$ \\
\hline Midwest & $60.9(57.6-64.3)$ & $39.0(35.7-42.4)$ & $70.4(67.2-73.3)$ & $29.6(26.6-32.8)$ \\
\hline \multicolumn{5}{|l|}{ Sex } \\
\hline Male & $60.3(58.5-62.1)$ & $39.7(37.9-41.5)$ & $68.5(67.1-69.9)$ & $31.5(30.1-32.9)$ \\
\hline Female & $61.1(59.4-62.7)$ & $38.9(37.3-40.6)$ & $68.8(67.5-70.2)$ & $31.2(29.8-32.5)$ \\
\hline \multicolumn{5}{|l|}{ Age } \\
\hline 18-29 years-old & $60.8(58.8-62.7)$ & $39.2(37.3-41.1)$ & $69.3(67.7-70.9)$ & $30.7(29.1-32.3)$ \\
\hline 30-39 years-old & $60.3(58.4-62.2)$ & $39.7(37.8-41.6)$ & $68.4(66.7-70.0)$ & $31.6(29.9-33.2)$ \\
\hline $40-49$ years-old & $61.1(59.0-63.1)$ & $38.9(37.9-40.9)$ & $68.4(66.7-70.1)$ & $31.6(29.9-33.3)$ \\
\hline $50-59$ years-old & $59.5(57.3-61.6)$ & $40.5(38.4-42.6)$ & $69.2(67.4-70.9)$ & $30.8(29.1-32.6)$ \\
\hline 60 years-old or more & $61.9(59.8-64.0)$ & $38.1(35.9-40.2)$ & $68.4(66.7-70.0)$ & $31.6(29.9-33.3)$ \\
\hline \multicolumn{5}{|l|}{ Skin color/race } \\
\hline White & $54.3(52.1-56.5)$ & $45.7(43.5-47.8)$ & $62.9(61.0-64.8)$ & $37.1(35.2-39.0)$ \\
\hline Brown & $68.5(66.9-70.1)$ & $31.5(29.9-33.1)$ & $74.2(73.0-75.4)$ & $25.8(24.5-27.4)$ \\
\hline Black & $62.4(59.6-65.1)$ & $37.6(34.9-40.4)$ & $71.5(69.5-73.4)$ & $28.5(26.6-30.4)$ \\
\hline Yellow & $45.6(38.5-52.9)$ & $54.4(47.1-61.5)$ & $65.6(57.2-73.0)$ & $34.4(26.9-42.8)$ \\
\hline Indigenous & $66.2(58.0-73.6)$ & $33.8(26.4-42.0)$ & $76.7(70.4-82.1)$ & $23.3(17.9-29.6)$ \\
\hline \multicolumn{5}{|l|}{ Family income (quintiles) } \\
\hline 1 (poorer) & $64.6(62.7-66.5)$ & $35.4(33.5-37.2)$ & $70.0(68.2-71.6)$ & $30.0(28.4-31.7)$ \\
\hline 2 & $74.1(71.9-76.2)$ & $25.9(23.8-28.0)$ & $80.0(78.8-81.3)$ & $20.0(18.7-21.2)$ \\
\hline 3 & $69.6(67.8-71.3)$ & $30.4(28.7-32.2)$ & $77.3(75.6-78.6)$ & $22.7(21.3-24.0)$ \\
\hline 4 & $61.5(59.5-63.6)$ & $38.5(36.4-40.5)$ & $69.7(68.0-71.4)$ & $30.2(28.6-31.9)$ \\
\hline 5 (richer) & $42.6(40.4-48.9)$ & $57.4(55.1-59.6)$ & $52.4(50.4-54.4)$ & $47.6(45.5-49.6)$ \\
\hline \multicolumn{5}{|l|}{ Household wealth quintiles } \\
\hline 1 (lower) & $79.1(77.2-80.9)$ & $20.9(19.0-22.8)$ & $82.9(81.6-84.1)$ & $17.1(15.8-18.4)$ \\
\hline 2 & $72.9(71.0-74.8)$ & $27.1(25.2-29.0)$ & $78.6(77.1-79.9)$ & $21.4(20.0-22.8)$ \\
\hline 3 & $67.1(65.0-69.2)$ & $32.9(30.8-35.0)$ & $71.8(69.9-73.7)$ & $28.2(26.3-30.1)$ \\
\hline 4 & $58.7(56.4-60.9)$ & $41.3(39.1-43.6)$ & $68.4(66.5-70.2)$ & $31.6(29.8-33.5)$ \\
\hline 5 (higher) & $40.8(38.1-43.5)$ & $59.2(56.5-61.9)$ & $53.7(51.4-56.0)$ & $46.3(43.9-48.6)$ \\
\hline \multicolumn{5}{|l|}{$\begin{array}{l}\text { Schooling of the head of } \\
\text { household }\end{array}$} \\
\hline None & $77.3(75.1-79.4)$ & $22.7(20.6-24.8)$ & $83.7(81.8-85.3)$ & $16.3(14.7-18.1)$ \\
\hline Incomplete Elementary / & $70.9(68.9-72.8)$ & $29.1(27.1-31.0)$ & $76.5(75.0-77.9)$ & $23.5(22.0-24.9)$ \\
\hline \multicolumn{5}{|l|}{ Middle school } \\
\hline Elementary / Middle school & $64.6(62.1-67.0)$ & $35.4(32.9-37.9)$ & $71.9(69.8-73.9)$ & $28.1(26.1-30.1)$ \\
\hline High school & $53.7(51.5-55.9)$ & $46.3(44.1-48.5)$ & $64.3(62.4-66.1)$ & $35.7(33.9-37.6)$ \\
\hline Undergraduation or more & $31.9(39.3-34.7)$ & $68.1(65.3-70.7)$ & $46.3(43.7-48.8)$ & $53.7(51.2-56.2)$ \\
\hline \multicolumn{5}{|l|}{$\begin{array}{l}\text { Search for health care in case of } \\
\text { illness }\end{array}$} \\
\hline Private & $54.9(51.5-58.4)$ & $45.1(41.6-48.5)$ & $47.3(405.1-49.4)$ & $52.7(50.6-54.9)$ \\
\hline Public & $78.5(76.8-80.0)$ & $21.5(19.9-23.2)$ & $74.6(72.8-76.4)$ & $25.4(23.6-27.2)$ \\
\hline Pharmacy/others & $67.9(61.9-73.4)$ & $32.1(26.6-38.1)$ & $62.8(57.5-67.7)$ & $37.2(32.2-42.5)$ \\
\hline
\end{tabular}


Table 2. Description of use of medical health services (public or private) according to registered in a family health unit $^{*}$ in 2013 and 2019.

\begin{tabular}{|c|c|c|c|c|}
\hline & \multicolumn{2}{|c|}{ Use of health services } & \multicolumn{2}{|c|}{ Use of health services } \\
\hline & $\begin{array}{l}\text { Registered in a } \\
\text { family health } \\
\text { unit } 2013\end{array}$ & $\begin{array}{l}\text { Not registered in } \\
\text { a family health } \\
\text { unit } 2013\end{array}$ & $\begin{array}{c}\text { Registered in a } \\
\text { family health unit } \\
2019\end{array}$ & $\begin{array}{l}\text { Not registered in } \\
\text { a family health } \\
\text { unit } 2013\end{array}$ \\
\hline & $\%(\mathrm{CI} 95 \%)$ & $\%(\mathrm{CI} 95 \%)$ & $\%(\mathrm{CI} 95 \%)$ & $\%(\mathrm{CI} 95 \%)$ \\
\hline \multicolumn{5}{|c|}{ Arterial hypertension } \\
\hline No & $59.0(57.3-60.7)$ & $41.0(39.2-42.7)$ & $68.9(67.2-70.7)$ & $31.0(29.3-32.8)$ \\
\hline Yes & $63.4(61.3-65.6)$ & $36.6(34.4-38.7)$ & $73.0(69.3-76.5)$ & $27.0(23.5-30.7)$ \\
\hline \multicolumn{5}{|l|}{ Diabetes } \\
\hline No & $59.1(57.4-60.7)$ & $40.9(39.2-42.6)$ & $68.9(67.1-70.6)$ & $31.1(29.4-32.9)$ \\
\hline Yes & $63.7(60.4-66.8)$ & $36.3(33.1-39.5)$ & $70.0(60.6-77.9)$ & $30.0(22.1-39.4)$ \\
\hline \multicolumn{5}{|c|}{ high cholesterol } \\
\hline No & $59.1(57.4-60.8)$ & $40.9(39.2-42.6)$ & $69.2(67.4-70.9)$ & $30.8(39.0-32.6)$ \\
\hline Yes & $60.9(58.3-63.5)$ & $39.1(36.4-41.6)$ & $66.9(61.2-72.1)$ & $33.1(27.9-38.7)$ \\
\hline \multicolumn{5}{|l|}{ Pregnancy } \\
\hline No & $59.1(57.4-60.8)$ & $40.9(39.2-42.6)$ & $68.5(66.2-70.7)$ & $31.5(29.3-33.8)$ \\
\hline Yes & $60.9(58.3-63.5)$ & $39.1(36.4-41.6)$ & $87.1(64.6-96.2)$ & $12.9(03.8-35.4)$ \\
\hline \multicolumn{5}{|c|}{ Self-perception of health } \\
\hline Very good & $47.4(44.6-50.1)$ & $52.6(49.8-55.4)$ & $57.7(55.3-60.0)$ & $42.3(39.9-44.7)$ \\
\hline Good & $58.2(56.4-60.1)$ & $41.8(39.9-43.6)$ & $67.2(65.7-68.7)$ & $32.8(31.3-34.3)$ \\
\hline Regular & $68.2(66.4-69.9)$ & $31.8(30.1-33.6)$ & $74.1(72.7-75.5)$ & $25.9(24.5-27.3)$ \\
\hline $\mathrm{Bad}$ & $72.3(69.9-74.6)$ & $27.7(25.4-30.1)$ & $78.2(76.2-80.0)$ & $21.8(20.0-23.8)$ \\
\hline Very bad & $69.6(65.2-73.7)$ & $30.4(26.3-34.7)$ & $76.2(72.5-79.5)$ & $23.8(20.5-27.5)$ \\
\hline
\end{tabular}

Source: Author's elaboration.

be measured only by access or use, but also by the effectiveness of the service. Pinto ${ }^{16}$ demonstrated a $45 \%$ reduction in hospitalizations for sensitive conditions for PHC in the period between 2001 and 2016. A result similar to that found by Mendonça et al. ${ }^{17}$ in Belo Horizonte. The undeniable advances in access and management of conditions sensitive to $\mathrm{PHC}$ seem to be running out of breath ${ }^{5,6}$. Currently, the indicators approved by the new PHC financing and made publicly available show a low number with semi-annual measured arterial tension (4\%), low number of diabetic patients with glycated hemoglobin tests (10\%), low number of pregnant women with 6 consultations. prenatal care being the first until the 20th week of pregnancy $(33 \%)$ and only $37 \%$ of Brazilian pregnant women with HIV and Syphilis tests requested in $\mathrm{PHC}^{11}$. These findings reveal that there is still an extensive agenda for implementing primary health care in Brazil, particularly if the impacts of the COVID-19 pandemic were considered for the near future ${ }^{18,19}$.

PNS 2019 data consolidate the movement of expansion of the FSH as the main strategy for PHC organization in Brazil, with characteristics that guarantee equity in the provision of services. There is a clear expansion of services when comparing the results obtained by the PNS 20132019, with a deepening of an equity relationship in the use of services in 2019. Despite this, the observed fact of the increase in the proportion of registered households may not guarantee that individuals residing in the household are registered and making regular use of public health services (SUS). In a recent study on PHC financing in Brazil, Hazheim et al. $(2020)^{7}$, pointed out that although there is an estimated covered population of $148,674,300$ million people, there were only 90 million people registered with the FHS. Despite the strong and necessary expansion of services experienced by Brazil in recent years, it is essential that this expansion becomes more effective care. In 2019, there was an army of people potentially covered by FSH services without registration. We can speculate that these people do not use the FHS health services or used them sporadically without the possibility of forming a bond.

Some limitations are inherent to the study, such as the interviewee / resident / resident providing the information collected by all the in- 
Table 3. Crude $^{\mathrm{c}}$ and adjusted ${ }^{\mathrm{a}}$ Logistic regression of associated factors to use of public health services (SUS) ( $\mathrm{n}=148,580 \mathrm{in} 2013$; $\mathrm{n}=207,845$ in 2019).

\begin{tabular}{|c|c|c|c|c|c|c|c|c|}
\hline \multirow[b]{2}{*}{ Co-variables } & \multicolumn{4}{|c|}{ PNS 2013} & \multicolumn{4}{|c|}{ PNS 2019} \\
\hline & $\mathrm{OR}^{\mathrm{c}}(\mathrm{IC} 95 \%)$ & $\begin{array}{c}P \\
\text { value }\end{array}$ & $\mathrm{OR}^{\mathrm{a}}(\mathrm{IC} 95 \%)$ & $\begin{array}{c}P \\
\text { value }\end{array}$ & $\mathrm{OR}^{\mathrm{c}}(\mathrm{IC} 95 \%)$ & $\begin{array}{c}P \\
\text { value }\end{array}$ & $\mathrm{OR}^{\mathrm{a}}(\mathrm{IC} 95 \%)$ & $\begin{array}{c}P \\
\text { value }\end{array}$ \\
\hline $\begin{array}{l}\text { Registered in a } \\
\text { family health unit }\end{array}$ & & $<0.001$ & & & & $<0.001$ & & 0.010 \\
\hline Yes & 1 & & 1 & $<0.001$ & 1 & & 1 & \\
\hline No & $0.61(0.56-0.66)$ & & $0.65(0.55-0.78)$ & & $0.68(63.2-73.64)$ & & $0.86(0.77-0.96)$ & \\
\hline Census situation & & 0.003 & & - & & 0.115 & & 0.012 \\
\hline Urban & 1 & & - & & 1 & & 1 & \\
\hline Rural & $1.14(1.05-1.24)$ & & & & $1.05(0.98-1.12)$ & & $0.87(0.78-0.97)$ & \\
\hline Region & & $<0.001$ & & 0.002 & & $<0.001$ & & $<0.001$ \\
\hline North & 1 & & 1 & & 1 & & 1 & \\
\hline Northeast & $1.23(1.11-1.37)$ & & $1.04(0.84-1.29)$ & & $1.17(1.09-1.26)$ & & $1.01(0.89-1.15)$ & \\
\hline Southeast & $1.27(1.14-1.42)$ & & $1.48(1.17-1.88)$ & & $1.19(1.11-1.30)$ & & $1.41(1.23-1.63)$ & \\
\hline South & $1.47(1.30-1.67)$ & & $1.36(1.04-1.78)$ & & $1.31(1.20-1.42)$ & & $1.53(1.32-1.78)$ & \\
\hline Midwest & $1.13(1.00-1.26)$ & & $1.08(0.84-1.39)$ & & $1.01(0.92-1.10)$ & & $1.07(0.92-1.26)$ & \\
\hline Sex & & $<0.001$ & & - & & $<0.001$ & & - \\
\hline Male & 1 & & - & & 1 & & - & \\
\hline Female & $1.85(1.74-1.96)$ & & & & $1.74(1.67-1.82)$ & & & \\
\hline Age & & $<0.001$ & & - & & $<0.001$ & & 0.004 \\
\hline 18-29 years-old & 1 & & - & & 1 & & 1 & \\
\hline 30-39 years-old & $1.14(1.04-1.25)$ & & & & $1.09(1.01-1.18)$ & & $1.09(0.92-1.29)$ & \\
\hline $40-49$ years-old & $1.50(1.38-1.63)$ & & & & $1.39(1.29-1.50)$ & & $1.21(1.01-1.44)$ & \\
\hline $50-59$ years-old & $1.98(1.81-2.16)$ & & & & $1.77(1.64-1.90)$ & & $1.27(1.07-1.51)$ & \\
\hline $\begin{array}{l}60 \text { years-old or } \\
\text { more }\end{array}$ & $2.47(2.26-2.69)$ & & & & $2.15(2.01-230)$ & & $1.04(0.87-1.23)$ & \\
\hline Skin color/race & & $<0.001$ & & - & & $<0.001$ & & - \\
\hline White & 1 & & - & & 1 & & - & \\
\hline Brown & $1.12(1.04-1.19)$ & & & & $1.14(1.08-1.20)$ & & & \\
\hline Black & $1.19(1.07-1.33)$ & & & & $1.30(1.20-1.40)$ & & & \\
\hline Yellow & $0.77(0.56-1.05)$ & & & & $0.98(0.67-1.44)$ & & & \\
\hline Indigenous & $1.63(1.15-2.30)$ & & & & $1.45(1.06-2.00)$ & & & \\
\hline $\begin{array}{l}\text { Family income } \\
\text { (quintiles) }\end{array}$ & & $<0.001$ & & 0.001 & & $<0.001$ & & 0.001 \\
\hline 1 (poorer) & 1 & & 1 & & 1 & & 1 & \\
\hline 2 & $0.99(0.89-1.10)$ & & $1.05(0.84-1.33)$ & & $1.24(1.15-1.33)$ & & $1.38(1.17-1.63)$ & \\
\hline 3 & $1.07(0.99-1.15)$ & & $1.00(0.81-1.25)$ & & $1.33(1.25-1.42)$ & & $1.13(0.97-1.31)$ & \\
\hline 4 & $0.67(0.62-0.73)$ & & $0.74(0.57-0.96)$ & & $0.92(0.85-0.98)$ & & $1.06(0.90-1.24)$ & \\
\hline 5 (richer) & $0.37(0.34-0.41)$ & & $0.57(0.42-0.77)$ & & $0.59(0.55-0.65)$ & & $0.82(0.68-0.97)$ & \\
\hline
\end{tabular}

habitants of the household. In addition, the PNS does not estimate data for geographic coverage smaller than the capitals ${ }^{8}$.

The National Health Survey represents fundamental relevance for the evaluation of health services and health conditions of the Brazilian population. A home-based and representative sample, with a broad research instrument focused on relevant outcomes for the country as modules that include: communicable diseases, sexual activity, chronic health conditions and medical care, with a focus on Primary Health Care (PHC) from the use of the Primary Care Assessment $\mathrm{Tool}^{8}$. It is worth mentioning the fundamental role of the Brazilian Institute of Geography and Statistics as the competent body for the development of population surveys with methodological rigor and the present efficiency and effectiveness 
Table 3. Crude ${ }^{\mathrm{c}}$ and adjusted ${ }^{\mathrm{a}}$ Logistic regression of associated factors to use of public health services (SUS) ( $\mathrm{n}=148,580$ in 2013 ; $\mathrm{n}=207,845$ in 2019).

\begin{tabular}{|c|c|c|c|c|c|c|c|c|}
\hline \multirow[b]{2}{*}{ Co-variables } & \multicolumn{4}{|c|}{ PNS 2013} & \multicolumn{4}{|c|}{ PNS 2019} \\
\hline & $\mathrm{OR}^{\mathrm{c}}(\mathrm{IC} 95 \%)$ & $\begin{array}{c}\mathbf{P} \\
\text { value }\end{array}$ & $\mathrm{OR}^{\mathrm{a}}(\mathrm{IC} 95 \%)$ & $\begin{array}{c}P \\
\text { value }\end{array}$ & $\mathrm{OR}^{\mathrm{c}}(\mathrm{IC} 95 \%)$ & $\begin{array}{c}P \\
\text { value }\end{array}$ & $\mathrm{OR}^{\mathrm{a}}(\mathrm{IC} 95 \%)$ & $\begin{array}{c}\mathbf{P} \\
\text { value }\end{array}$ \\
\hline $\begin{array}{l}\text { Household wealth } \\
\text { quintiles }\end{array}$ & & $<0.001$ & & $<0.001$ & & $<0.001$ & & $<0.001$ \\
\hline 1 (lower) & 1 & & 1 & & 1 & & 1 & \\
\hline 2 & $0.99(0.90-1.10)$ & & $0.97(0.75-1.25)$ & & $0.98(0.91-1.04)$ & & $0.95(0.84-1.08)$ & \\
\hline 3 & $0.92(0.83-1.01)$ & & $0.95(0.73-1.24)$ & & $0.86(0.80-0.93)$ & & $0.99(0.86-1.15)$ & \\
\hline 4 & $0.72(0.65-0.80)$ & & $0.93(0.70-1.24)$ & & $0.69(0.63-0.74)$ & & $0.86(0.74-0.99)$ & \\
\hline 5 (higher) & $0.39(0.34-0.44)$ & & $0.50(0.35-0.73)$ & & $0.50(0.45-0.55)$ & & $0.69(0.57-0.83)$ & \\
\hline $\begin{array}{l}\text { Schooling of the } \\
\text { head of household }\end{array}$ & & $<0.001$ & & - & & $<0.001$ & & - \\
\hline None & 1 & & - & & 1 & & - & \\
\hline $\begin{array}{l}\text { Incomplete } \\
\text { Elementary / } \\
\text { Middle school }\end{array}$ & $1.05(0.94-1.16)$ & & & & $0.98(0.88-1.09)$ & & & \\
\hline $\begin{array}{r}\text { Elementary / } \\
\text { Middle school }\end{array}$ & $0.79(0.70-0.89)$ & & & & $0.76(0.68-0.86)$ & & & \\
\hline High school & $0.61(0.55-0.68)$ & & & & $0.61(0.55-0.68)$ & & & \\
\hline $\begin{array}{l}\text { Undergraduation } \\
\text { or more }\end{array}$ & $0.32(0.26-0.39)$ & & & & $0.43(0.37-0.50)$ & & & \\
\hline $\begin{array}{l}\text { Arterial } \\
\text { hypertension }\end{array}$ & & $<0.001$ & & 0.001 & & $<0.001$ & & $<0.001$ \\
\hline No & 1 & & 1 & & 1 & & 1 & \\
\hline Yes & $2.28(2.08-2.50)$ & & $1.42(1.15-1.76)$ & & $2.00(1.87-2.13)$ & & $1.31(1.07-1.52)$ & \\
\hline Diabetes & & $<0.001$ & & - & & $<0.001$ & & \\
\hline No & 1 & & - & & 1 & & & - \\
\hline Yes & $2.22(1.94-2.53)$ & & & & $1.94(1.77-2.13)$ & & - & \\
\hline High cholesterol & & $<0.001$ & & 0.017 & & $<0.001$ & & $<0.001$ \\
\hline No & 1 & & 1 & & 1 & & 1 & \\
\hline Yes & $1.93(1.74-2.14)$ & & $1.35(1.05-1.72)$ & & $1.85(1.70-2.01)$ & & $1.39(1.24-1.57)$ & \\
\hline Pregnancy & & $<0.001$ & & $<0.001$ & & $<0.001$ & & $<0.001$ \\
\hline No & 1 & & 1 & & 1 & & 1 & \\
\hline Yes & $2.82(2.21-3.63)$ & & $3.51(2.53-4.87)$ & & $3.86(3.04-4.91)$ & & $6.11(4.46-8.00)$ & \\
\hline $\begin{array}{l}\text { Self-perception of } \\
\text { health }\end{array}$ & & $<0.001$ & & $<0.001$ & & $<0.001$ & & $<0.001$ \\
\hline Very good & 1 & & 1 & & 1 & & 1 & \\
\hline Good & $1.71(1.46-1.99)$ & & $1.61(1.14-2.28)$ & & $1.50(1.37-1.64)$ & & $1.28(1.08-1.52)$ & \\
\hline Regular & $4.99(4.27-5.82)$ & & $4.05(2.81-5.83)$ & & $3.67(3.35-4.03)$ & & $2.51(2.09-3.00)$ & \\
\hline $\mathrm{Bad}$ & $9.63(8.12-11.42)$ & & $7.71(4.78-12.44)$ & & $7.18(6.42-8.03)$ & & $3.86(3.04-4.90)$ & \\
\hline Very bad & $14.12(11.36-17.6)$ & & $12.07(6.24-23.4)$ & & $9.62(8.24-11.23)$ & & $4.65(3.45-6.26)$ & \\
\hline
\end{tabular}

${ }^{*}$ sex was not included in the adjusted model due high correlation with pregnancy.

Source: Author's elaboration.

in the development of data collection activities. Many of these surveys already established by the use of data carried out by the Brazilian scientific community ${ }^{14,18-20}$. Without national home-based surveys that provide relevant information on the
Brazilian population, such as the National Health Survey, National Household Sample Survey and the Census, the country is in the dark and public policy planning, development and evaluation are exposed to ideological obscurantism. 


\section{Collaborations}

OP D'Avila worked on the study design, analysis and interpretation of data and final review. LB Cleff assisted in the literature review, formatting of the article. LA Chisini, FC Santos, MG Cade- martori contributed to the study design, data analysis and final review of the text. EC Castilho contributed to the study design, data interpretation and final review. All authors approved the final version of the text.

\section{References}

1. Starfield B. Primary care: concept, evaluation and policy. New York: Oxford University Press; 1992.

2. Starfield B. Atención Primaria: equilibrio entre necesidades de salud, servicios y tecnología. Barcelona: Masson; 2002.

3. Macinko J, Mendonça CS. Estratégia Saúde da Família, um forte modelo de Atenção Primária à Saúde que traz resultados. Saude em Debate 2018; 42(1):18-37.

4. Harzheim E, Santos CMJ, D’Avila OP, Wollmann L, Pinto LF. Bases para a reforma da Atenção Primária à Saúde no Brasil em 2019: mudanças estruturantes após 25 anos do Programa de Saúde da Família. Rev Bras Med Fam Comunidade 2020; 15(42):2354

5. Rocha R, Soares R. Evaluating the impact of community-based health interventions: evidence from Brazil's Family Health Program. Health Econnomics 2010; 129(51):126-158.

6. Bastos ML, Menzies D, Hone T, Dehghani K, Trajman A. Correction: The impact of the Brazilian family health on selected primary care sensitive conditions: A systematic review. PLoS One 2017; 12(12):e0189557

7. Harzheim E, D'Avila OP, Ribeiro DC, Ramos LG, Silva LE, Santos CMJ, Costa LGM, Cunha CRH, Pedebos LA. Novo financiamento para uma nova Atenção Primária à Saúde no Brasil. Cien Saude Colet 2020; 25(4):1361-1374.

8. Stopa SR, Szwarcwald CL, Oliveira MM, Gouvea ECDP, Vieira MLFP, Freitas MPS, Sardinha LMV, Macário EM. Pesquisa Nacional de Saúde 2019: histórico, métodos e perspectivas. Epidemiol Serv Saude 2020; 29(5):1-12.

9. Costa NR. A Estratégia de Saúde da Família, a atenção primária e o desafio das metrópoles brasileiras. Cien Saude Colet 2016;21(5):1389-1398.

10. Viana ALD, Dal Poz MR. A Reforma do Sistema de Saúde do Brasil e o Programa Saúde da Família. Physis 1998; 8(2):16.

11. Brasil. Ministério da Saúde (MS). Painéis de Indicadores da Atenção Primária à Saúde. [página de internet]. [Acessado 2021 maio 26]. Disponível em: https://sisaps.saude.gov.br/painelsaps/saude-familia

12. Capilheira MF, Santos IS. Fatores individuais associados à utilização de consultas médicas por adultos. Rev Saude Publica 2006; 40(3):436-443.

13. Travassos C, Viacava F, Pinheiro R, Brito A. Utilização dos serviços de saúde no Brasil. Rev Panam Salud Publica 2002; 11(5/6):365-373.
14. Malta DC, Leal MC, Costa MFL, Morais Neto OL. Inquéritos nacionais de saúde: experiência acumulada e proposta para o inquérito de saúde brasileiro. Rev Brasileira Epidemiol 2008; 11(1):159-167.

15. Baumgarten A, Peron TB, Bastos JL, Toassi RFC, Hilgert JB, Hugo FN, Celeste RK. Experiências de discriminação relacionadas aos serviços de saúde: análise exploratória em duas capitais do Sul do Brasil. Epidemiol Serv Saude 2015; 24(3):353-362.

16. Pinto LF, Giovanella L. Do Programa à Estratégia Saúde da Família: expansão do acesso e redução das internações por condições sensíveis à atenção básica (ICSAB). Cien Saude Colet 2018; 23(6):1903-1913.

17. Mendonça CS, Harzheim E, Duncan BB, Nunes LN, Leyh Werner. Trends in hospitalizations for primary care sensitive conditions following the implementation of Family Health Teams in Belo Horizonte, Brazil. Health Policy and Planning 2012; 27:348-355.

18. Pinto LF, Freitas MPS, Figueredo AWS. Sistemas Nacionais de Informação e levantamentos populacionais: algumas contribuições do Ministério da Saúde e do IBGE para a análise das capitais brasileiras nos últimos 30 anos. Cien Saude Colet 2018; 23(6):18591870.

19. Malta DC, Santos MAS, Stopa SR, Vieira JEB, Melo EA, Reis AAC. A Cobertura da Estratégia de Saúde da Família (ESF) no Brasil, segundo a Pesquisa Nacional de Saúde, 2013. Cien Saude Colet 2016; 21(2):327-338.

20. Malta DC, Stopa SR, Szwarcwald CL, Gomes NL, Junior JBS, Reis AAC. A vigilância e o monitoramento das principais doenças crônicas não transmissíveis no Brasil - Pesquisa Nacional de Saúde, 2013. Rev Bras Epi 2015; 18(2):3-16.

Article submitted 27/05/2021

Approved 29/05/2021

Final version submitted 31/05/2021

Chief editors: Maria Cecília de Souza Minayo, Romeu Gomes, Antônio Augusto Moura da Silva 